J. Kyushu Dent. Soc. 53 ( 3 ) : 363 379, 1999.

\title{
X-Ray Densitometric, Light-Microscopic and Ultrastructural Study on Dietary Treatment of Mandibular Bone Loss in Rats During Childhood
}

\author{
Ryuichi Nakashima, Zu-Yan Zhang, Wen-Yu Dai, \\ Kenshi Maki and Takahiro Nishioka \\ Department of Pediatric Dentistry (Director: Prof. Mitsutaka Kimura) \\ Kyushu Dental College, Kitakyushu, Japan
}

Key words: Densitometry/Microscopy/Mandible/Bone loss/Childhood

Accepted on April 26, 1999.

\section{Introduction}

Childhood is a remarkable phase for the growth and development of the individuals. At this age level the primary dentition is completed to erupt and supported by the jaw bone in the oral cavity via roots embedded in bone. According to Scammon's ${ }^{1)}$ developmental curves of the living tissues, during childhood lymphoid type develops sharply while neural type does slowly to adjust to the functions of tissues. The growth of general type is later than that of lymphoid and neural types, and at the primary sexual characteristic stage the growths of height, body weight and bone reach their peak respectively. Moreover, genital type develops suddenly and rapidly at the second sexual characteristic stage, also named as puberty. Jaw oral functions are associated with the occlusive power and masticatory ability, and develop satisfactorily with the growth of the face and skull. On the areas of matrix formation in the growing jaw bone appears a lot of vascularity while most bone lacunae lie scattered on the surface of the matrix around the vascular foramina, showing marked formation of bone matrix. Of all the jaw bones, the alveolar bones, possessing the supporting tissues of teeth, are membrane bones, which are formed through the differentiation of mesenchymal cell $\$$ into osteoblasts in addition to the existence of mineral. Therefore, the intestinal resorption of calcium seems important, but by now there is little known about the machanism between calcium and dietary treatments of bone matrix formation of the mandible during childhood. Herein, we fed 5-week-old Wistar male rats (corresponding to childhood in human beings) on low-calcium diet (calcium component is $30 \%$ of standard diet) so as to bring about bone loss in them, and then treated them with dietary treatments. Later, we observed bone matrix formation of the mandible and obtained some findings as follows.

\section{Materials and Methods}

\section{Animals and Treatments}

Thirty Wistar male rats of 5 weeks old, corresponding to childhood in human beings, were 
Table 1 The composition and content of mineral mixture

\begin{tabular}{c|c|c|c}
\hline \hline & Control group & Ca-deficient diet group & Ca-low deficient diet group (30\%) \\
\hline $\mathrm{Ca}$ & 480 & 0.01 & 144 \\
$\mathrm{P}$ & 650 & 612 & 612 \\
$\mathrm{Mg}$ & 87 & 87 & 87 \\
$\mathrm{Na}$ & 220 & 293 & 293 \\
$\mathrm{~K}$ & 440 & 746 & 746 \\
$\mathrm{Fe}$ & 32 & 32 & 32 \\
$\mathrm{Cu}$ & 0.46 & 0.5 & 0.5 \\
$\mathrm{Zn}$ & 3.4 & 3.0 & 3.0 \\
$\mathrm{Mn}$ & 1.6 & 2.6 & 2.6 \\
1 & 0.46 & 0.3 & 0.3 \\
$\mathrm{Cl}$ & 170 & 174 & 174 \\
\hline
\end{tabular}

randomly devided into 3 groups as follows. In the control group, rats were fed on a standard diet with tap water for 6 weeks. In the low calcium experimental group, rats were fed on a low calcium diet (calcium component is $30 \%$ of standard diet) with tap water for 3 weeks; then they were fed on standard diet with tap water for further 3 weeks. In the calcium deficient experimental group, rats were fed on a no-calcium-component diet with distilled water for 3 weeks; then they were treated the same as the low calcium experimental group for further 3 weeks. All the rats' food was made for this study by Oriental Yeast (Tokyo, Japan). The content of the feed was shown on Table 1. All the rats were housed in the animal room, of which the temperature was $22 \pm 2{ }^{\circ} \mathrm{C}$, the humidity was $50 \pm 5 \%$ and the lighting time was from $8 \mathrm{a} . \mathrm{m}$. to $8 \mathrm{p} . \mathrm{m}$.. The rats were weighed every day during feeding. Following 6 weeks of feeding, the rats were sacrificed under anesthesia with intraperitoneal injection of pentobarbital sodium (Nippon Pharma, Japan). Their mandibles were removed and later treated for densitometric measurement, microanalysis for $\mathrm{Ca}$ and $\mathrm{P}$, lightmicroscopic observations, and scanning electron microscopic observations. The animals were handled with adherence to the principles on the use of experimental animals outlined by Kyushu Dental College.

2. Densitometric measurement

The mandibles were kept in $10 \%$ neutral buffered formalin solution. These samples were imaged with Softex CSM at $28 \mathrm{kVp}, 6 \mathrm{~mA}, 60 \mathrm{~s}$ and focus-film distance of $70 \mathrm{~cm}$ with Fuji softex film FG and aluminum reference wedge attached. These films were observed by Microphotometer (Desitometer PDS-15, Konica, Japan). The survey light passed from the bottom border of the mandible to the top border of the mandibular alveolar bone at speed of $0.1 \mathrm{~mm} / \mathrm{s}$. Scanning was carried out with slit of $10 \times 500 \mu \mathrm{m}$.

3. Sample preparation for microanalysis for $\mathrm{Ca}$ and $\mathrm{P}$

The samples were cut from the incisor alveolar crest to $1 \mathrm{~mm}$ in front of the molar area, at thickness of $3 \mathrm{~mm}$, vertical to the mandibular border, by dental diamond disk (\#62, Shofu, 
Kyoto, Japan) with spraying water. After fixation with $10 \%$ neutral buffered formalin solution, these samples were dehydrated through a graded ethanol series and treated in 2methyl- $\alpha$-propanol, dried in $t$-butyl alcohol by freeze-drying (ID-2, Japanese Electric, Japan). Sections were embedded in resin, then abraded, polished, and sputtered with aurum. Later they were observed under a scanning microscope (JSM T-300, Japanese Electric) equipped with energy-dispersive $\mathrm{X}$-ray microanalysis (JED-2000, Japanese Electric) to do area anqlysis on examining the distribution of calcium $(\mathrm{Ca})$ and phosphate $(\mathrm{P})$, and point analysis on determining the content of $\mathrm{Ca}$ and $\mathrm{P}$.

4. Sample preparation for light-microscopy

The samples were cut from the incisor alveolar crest to $1 \mathrm{~mm}$ in front of the molar area. After fixation with $10 \%$ neutral buffered formalin solution, these samples were decalcified in $5 \%$ nitric acid solution for $24 \mathrm{~h}$, dehydrated through a graded ethanol series, and embedded in paraffin (Fisher Scientific, USA). Sections of $7 \mu \mathrm{m}-15 \mu \mathrm{m}$ thick were cut consecutively, stained with hematoxylin and eosin, and observed under light-microscope.

5. Sample preparation for scanning electron microscopy (SEM)

The samples were cut as in preparation for $\mathrm{x}$-ray microanalysis, and fixed with $2.5 \%$ glutaraldehyde for $1 \mathrm{~h}$ after being cleaned with $10 \%$ sodium hypochlorite solution by supersonic vibration to eliminate adhesion. They were rinsed by phosphate buffer ( $\mathrm{pH} 7.2)$ before postfixation. Postfixation were performed in $1 \%$ osmic acid buffer solution ( $\mathrm{pH} 7.2$ ) under $4{ }^{\circ} \mathrm{C}$ for $2 \mathrm{~h}$. After fixation, these samples were dehydrated through a graded ethanol series, treated with 2-methyl- $\alpha$-propanol, dried in t-butyl alcohol by freeze-drying (ID-2, Japanese Electric). Specimens were sputter-coated with gold and later observed under a scanning electron microscope (JSM-300, Japanese Electric).

\section{Results}

\section{X-ray findings}

$\mathrm{X}$-ray findings were observed from the films taken for densitometric measurement. In the control group, bone structure of the mandibular alveolus was dense and regularly-alignmented, and the thick alveolar bone surrounded the root of the incisor (Fig. 1). Compared with the control group, the calcium deficient group showed the thin alveolar bone, and sparse and irregularlyarranged trabeculae (Fig. 2). Compared with the calcium deficient group, the low calcium group showed increased thickness of the alveolar bone and somewhere dense bone structure was seen. But compared with the control group, the low calcium group showed

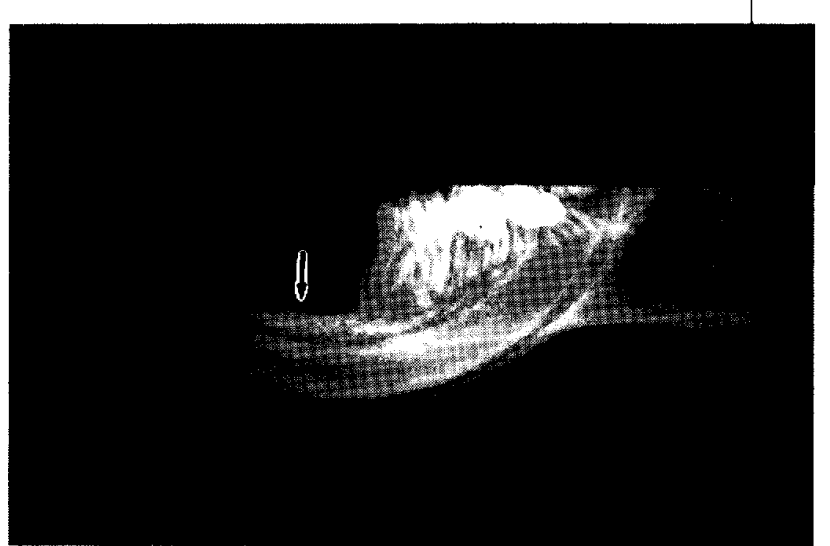

Fig. 1 Radiogram of the 6 th week. Control group Arrow : Alveolar bone 


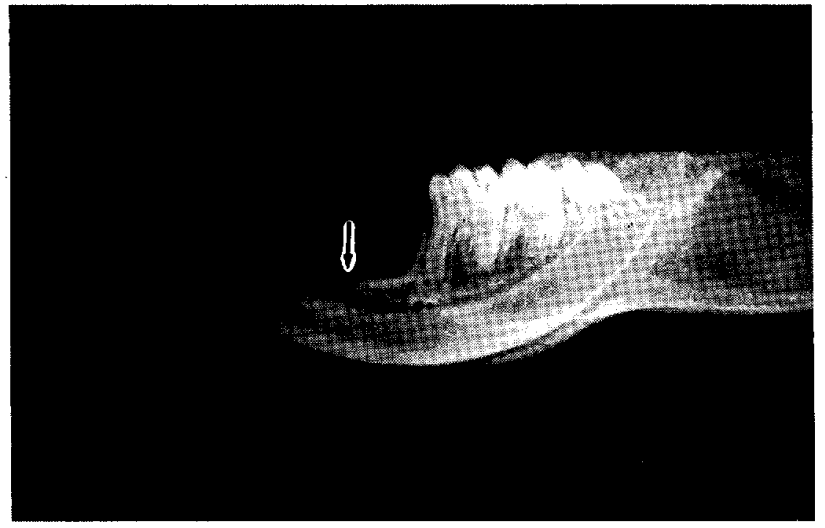

Fig. 2 Radiogram of the 6 th week. Ca-deficient diet group Arrow: Alveolar bone

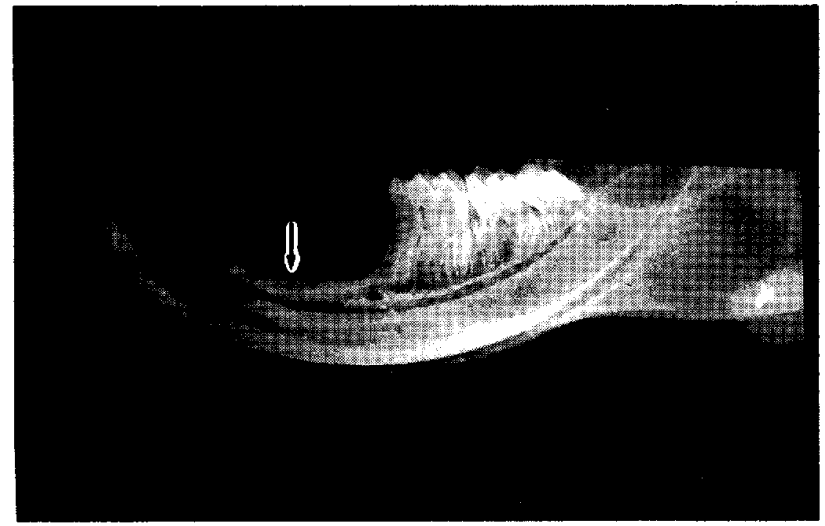

Fig. 3 Radiogram of the 6 th week. Ca-low deficient diet group

Arrow: Alveolar bone

Table 2 Bone shadow density of the alveolar bone in the equivalent of alminum

$(\mathrm{mm})$

\begin{tabular}{c|c}
\hline \hline Group & Density \\
\hline Control group & $2.20 \pm 0.38$ \\
\hline $\mathrm{Ca}$-deficient $\rightarrow$ normal diet group & $1.75 \pm 0.15$ \\
\hline $\mathrm{Ca}$-low deficient $\rightarrow$ normal diet group & $1.83 \pm 0.24$ \\
\hline
\end{tabular}

Table 3 Difference of bone shadow density in alveolar bone among the 3 group

\begin{tabular}{c|c|c|c}
\hline \hline & $\mathrm{A} \Leftrightarrow \mathrm{B}$ & $\mathrm{A} \Leftrightarrow \mathrm{C}$ & $\mathrm{B} \Leftrightarrow \mathrm{C}$ \\
\hline Density & $*$ & - & - \\
\hline \multicolumn{3}{c}{$*: \mathrm{p}<0.05$}
\end{tabular}
A : Control group
$\mathrm{B}: \mathrm{Ca}-$ deficient $\rightarrow$ normal diet group
C : Ca-low deficient $\rightarrow$ normal diet group

sparse bone structure in an overall observation of the alveolar bone (Fig. 3).

\section{Densitometric measurement}

The results of densitometric measurement in the control and experimental groups are presented in Table 2 and 3 . The calcium deficient group showed significantly lower density compared with the control group $(p<0.05)$. 
Table 4 Relative percentage of the $\mathrm{Ca}$ and $\mathrm{P}$ in alveolar bone by microanalysis

\begin{tabular}{c|c|c}
\hline \hline & $\mathrm{Ca}$ & $\mathrm{P}$ \\
\hline Control group & $76.55 \pm 1.22$ & $23.45 \pm 1.72$ \\
\hline Ca-deficient $\rightarrow$ normal diet group & $73.52 \pm 1.57$ & $26.48 \pm 1.57$ \\
\hline $\mathrm{Ca}$-low deficient $\rightarrow$ normal diet group & $73.69 \pm 1.56$ & $26.31 \pm 1.56$ \\
\hline \multicolumn{2}{|c}{ Mean \pm S. D. }
\end{tabular}

Table 5 Differences of $\mathrm{Ca}$ and $\mathrm{P}$ of alveolar bone by quantitative $\mathrm{X}$-ray microanalysis between the control group and the experimental group

\begin{tabular}{c|c|c|c}
\hline \hline & $\mathrm{A} \Leftrightarrow \mathrm{B}$ & $\mathrm{A} \Leftrightarrow \mathrm{C}$ & $\mathrm{B} \Leftrightarrow \mathrm{C}$ \\
\hline $\mathrm{Ca}$ & $*$ & $*$ & - \\
\hline $\mathrm{P}$ & $*$ & $*$ & - \\
\hline
\end{tabular}

$*: \mathrm{p}<0.05$
A : Control group
B : Ca-deficient $\rightarrow$ normal diet group
C : Ca-low deficient $\rightarrow$ normal diet group

Table 6 Relative ratio of $\mathrm{Ca}$ and $\mathrm{P}$ of alveolar bone by quantitative $\mathrm{X}$-ray microanalysis

\begin{tabular}{c|c|c}
\hline & $\mathrm{Ca} /[\mathrm{P}] \mathrm{c}$ & $\mathrm{P} /[\mathrm{P}] \mathrm{c}$ \\
\hline Control group & 1 & 1 \\
\hline Ca-deficient $\rightarrow$ normal diet group & 0.96 & 1.13 \\
\hline Ca-low deficient $\rightarrow$ normal diet group & 0.96 & 1.12 \\
\hline
\end{tabular}

\section{Microanalysis for $\mathrm{Ca}$ and $\mathrm{P}$}

The results of microanalysis for $\mathrm{Ca}$ and $\mathrm{P}$ in the control and experimental groups are presented in Tables 4, 5 and 6 . The experimental groups showed significantly lower $\mathrm{Ca} / \mathrm{P}$ ratio compared with the control group $(p<0.05)$. The experimental groups showed lower relative ratio of $\mathrm{Ca}$ than the control group, but there is no significant difference between the 


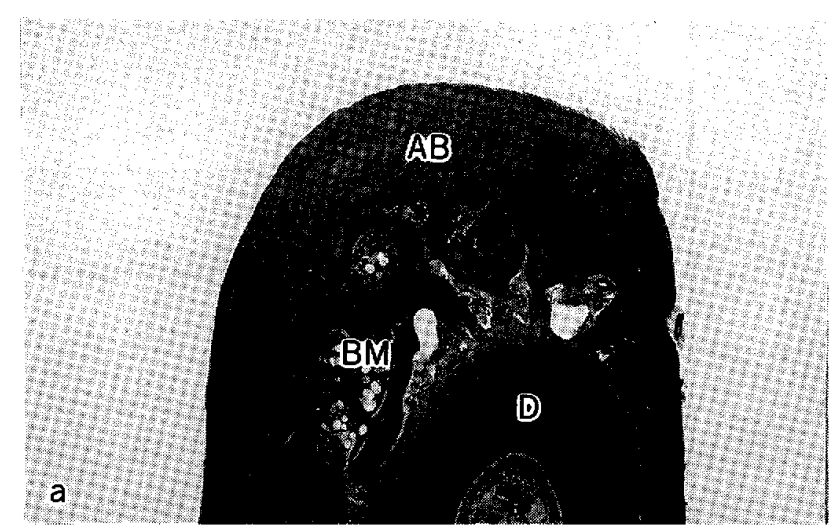

$\mathrm{H} \cdot \mathrm{E}$ stain $(\times 20)$

AB : Alveolar bone (lingual)

$\mathrm{BM}$ : Bone marrow

D : Dentin

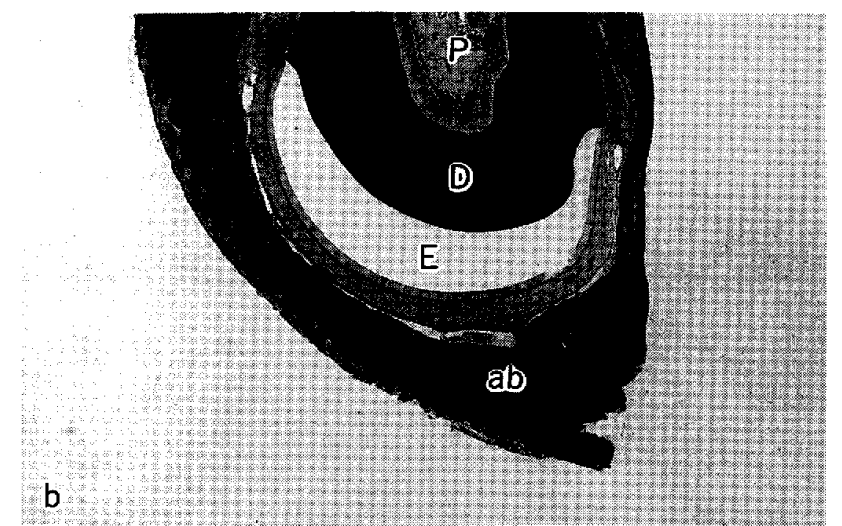

$\mathrm{H} \cdot \mathrm{E}$ stain $(\times 20)$

ab: Alveolar bone (labial)

D : Dentin

E : Enamel

$\mathrm{P}$ : Pulp

Fig. 4 Alveolar bone of the 6 th week.

Control group

experimental groups. The relative ratio of $\mathrm{P}$ showed a decreasing tendency on a sequence of the calcium deficient group, low calcium group and control group.

\section{Histopathologic Findings}

Compared with the control group, the calcium deficient group showed irregular periodontal membrane in the lingual, medial, and buccal or labial alveolar bone, markedly decreased bone lacunae and Haversian system in number, suggesting decreased bone matrix formation. The low calcium group showed increased bone lacunae, Haversian system in number and bone matrix formation when compared with the calcium deficient group; but insufficient bone remoddeling and restoration could be seen in the low calcium group when compared with the control group. (Figs. $4-7$ )

\section{SEM findings}

\section{Control group}

In the formation areas of bone matrix, the resting surface was adjancent to the resorption surface. On the formation surface of bone matrix appeared many collagen bundles in a particular alignment. There were many bone lacunae, at the wall of which collagen fibers were seen crossed. Other dense collagen fibers crossed into the a network on the upper surface of bone matrix. In the spaces among the collagen fibers, the mouths of bone canalicali were observed (Figs. 8, 9). On the bone resorption surface, there were many irregular-shaped lacunae of bone resorption. On the shallow and rough bottom of the bone resorption lacunae, slender collagen fibers were seen crossed into a network and many micronized calcareous depositions appeared collective, or cross, or broken-off, or granulated, or vanished.

Calcium deficient group

Compared to the control group, many large or small bone lacunae emerged, which was 


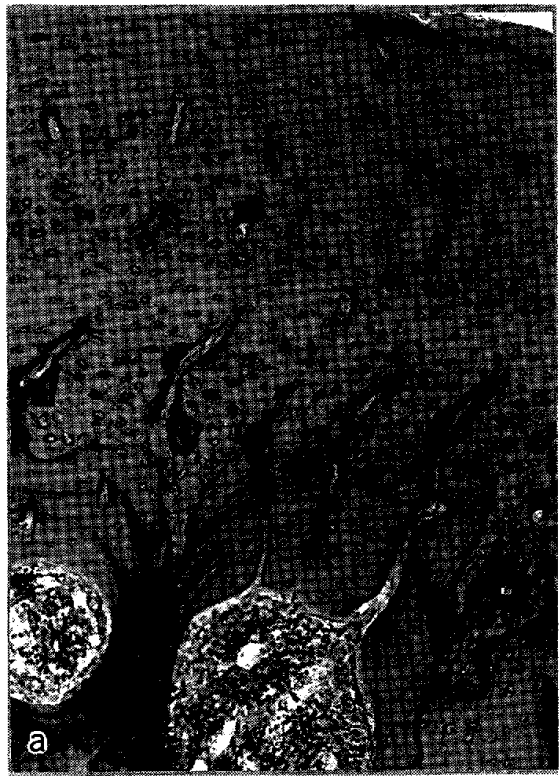

A higher magnification of Fig. 4-a. $\mathrm{H} \cdot \mathrm{E}$ stain $(\times 100)$

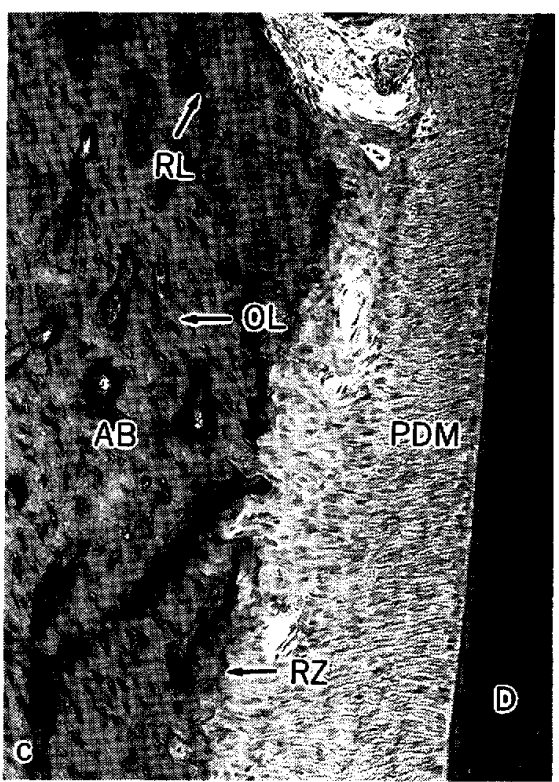

A higher magnification of Fig. 4-b. $\mathrm{H} \cdot \mathrm{E}$ stain $(\times 100)$

$\mathrm{AB}$ : Alveolar bone (buccal)

RL : Remodeling layer

$\mathrm{OL}$ : Osteocytic lacunae

PDM : Periodontal membrane

RZ : Resorptive zone

D : Dentin

Fig. 5 Examination with higher magnification.

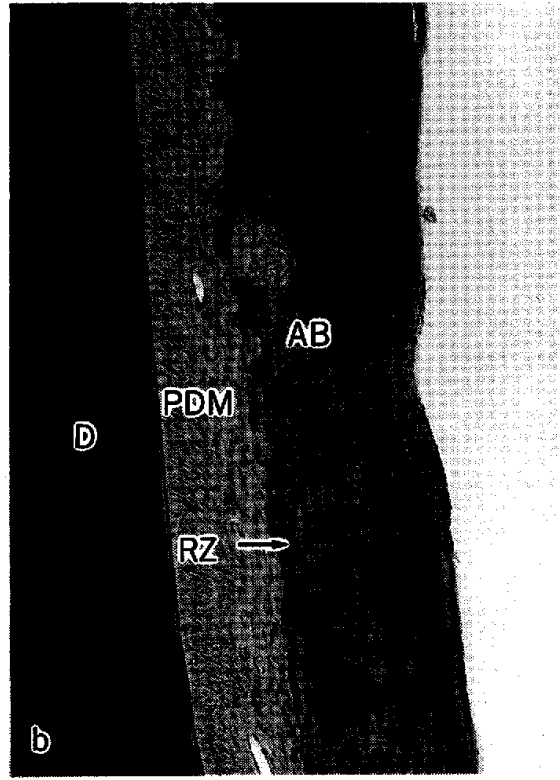

A higher magnification of Fig. 4-a. $\mathrm{H} \cdot \mathrm{E}$ stain $(\times 100)$

$\mathrm{AB}$ : Alveolar bone (central)

PDM : Periodontal membrane

$\mathrm{RZ}$ : Resorptive zone

Pap : Papillary layer

D : Dentin

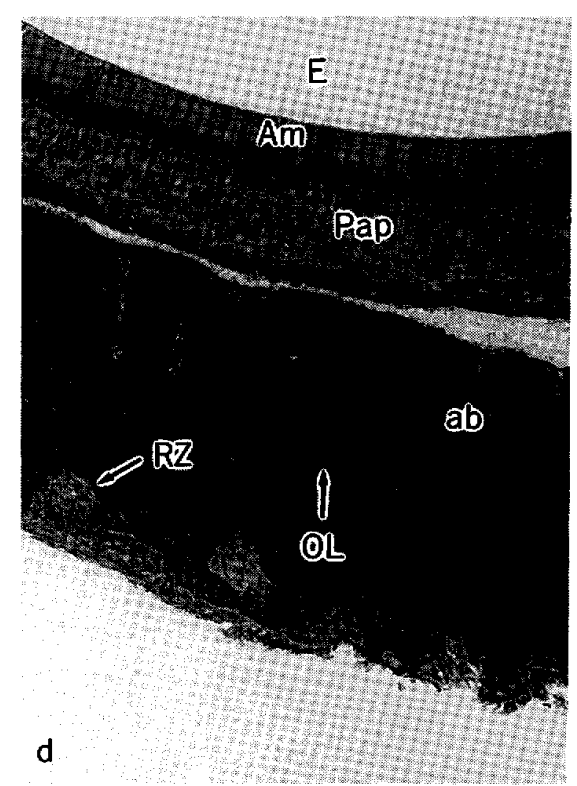

A higher magnification of Fig. 4-b.

$\mathrm{H} \cdot \mathrm{E}$ stain $(\times 100)$

$\mathrm{ab}$ : Alveolar bone (labial)

E : Enamel

Am : Ameloblast

RZ : Resorptive zone

OL : Osteocytic lacunae

Pap : Papillary layer 


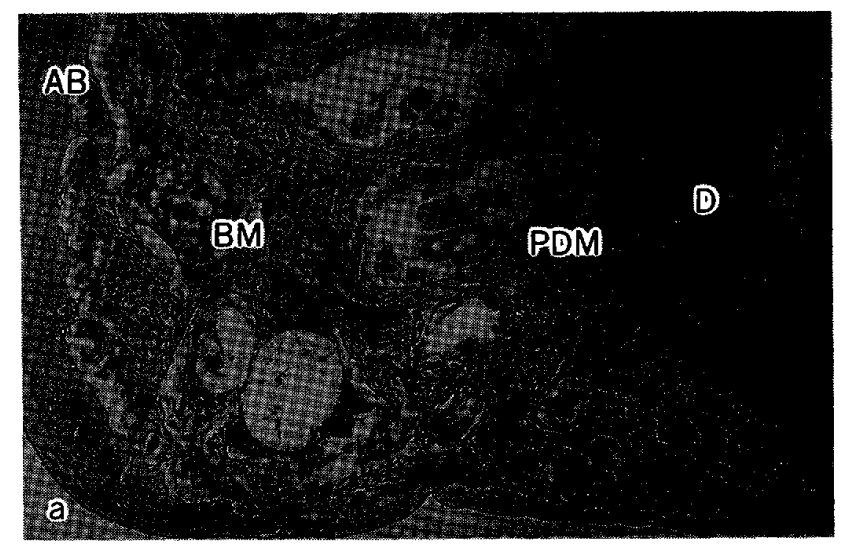

$\mathrm{H} \cdot \mathrm{E}$ stain $(\times 50)$

$\mathrm{AB}$ : Alveolar bone (lingual)

BM : Bone marrow

PDM : Periodontal membrane

D : Dentin

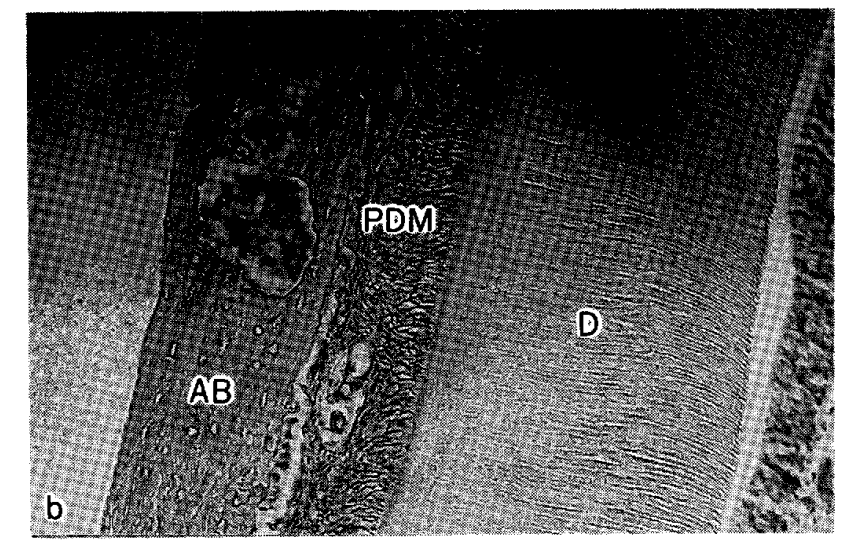

$\mathrm{H} \cdot \mathrm{E}$ stain $(\times 100)$

AB : Alveolar bone (central)

D : Dentin

PDM : Periodontal membrane

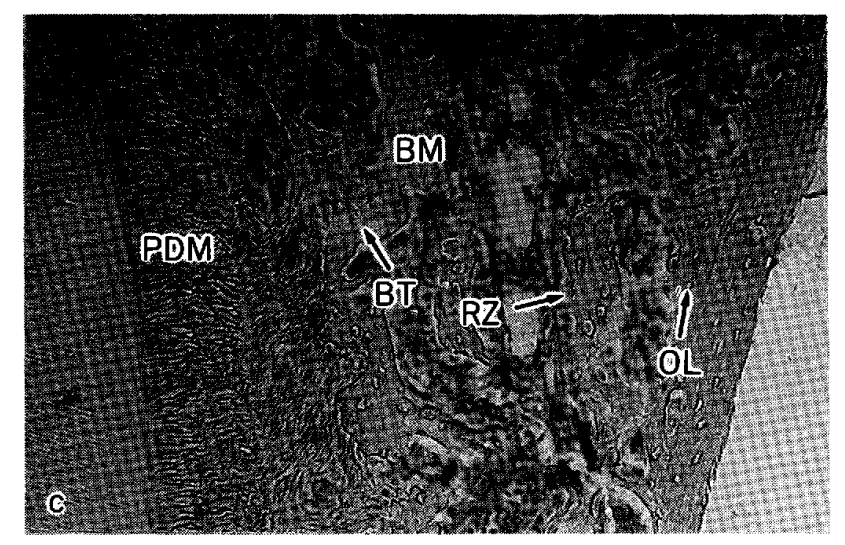

$\mathrm{H} \cdot \mathrm{E}$ stain $(\times 100)$

AB : Alveolar bone (buccal)

PDM : Periodontal membrane

RZ : Resorptive zone

OL : Osteocytic lacunae

$\mathrm{BM}$ : Bone marrow

BT : Bone trabecula

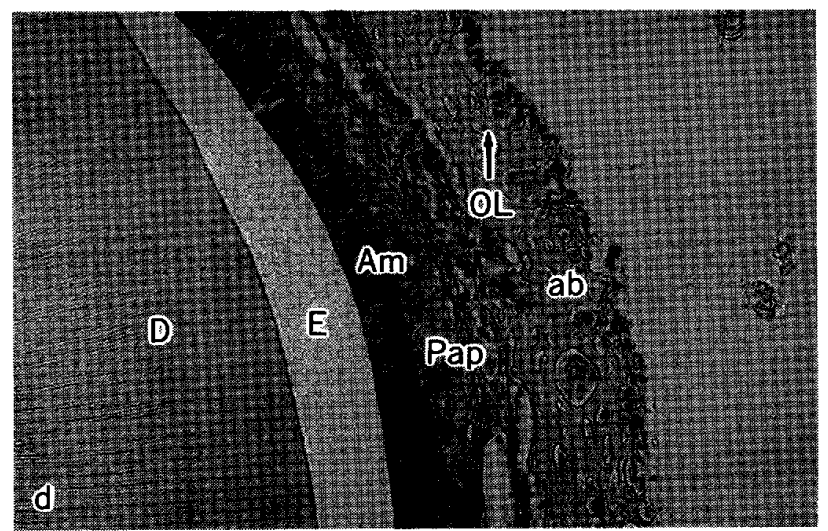

$\mathrm{H} \cdot \mathrm{E}$ stain $(\times 100)$

$\mathrm{ab}$ : Alveolar bone (lingual)

D : Dentin

E : Enamel

Am : Ameloblast

OL : Osteocytic lacunae

Pap: Papillary layer

Fig. 6 Alveolar bone of the 6 th week.

Ca-deficient diet group 


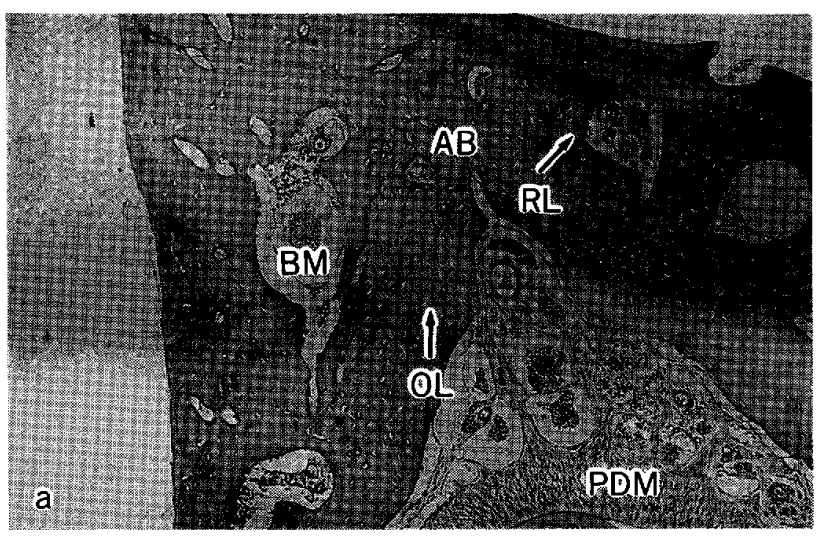

$\mathrm{H} \cdot \mathrm{E}$ stain $(\times 50)$

AB : Alveolar bone (lingual)

BM : Bone marrow

PDM : Periodontal membrane

OL : Osteocytic lacunae

RL : Remodeling layer

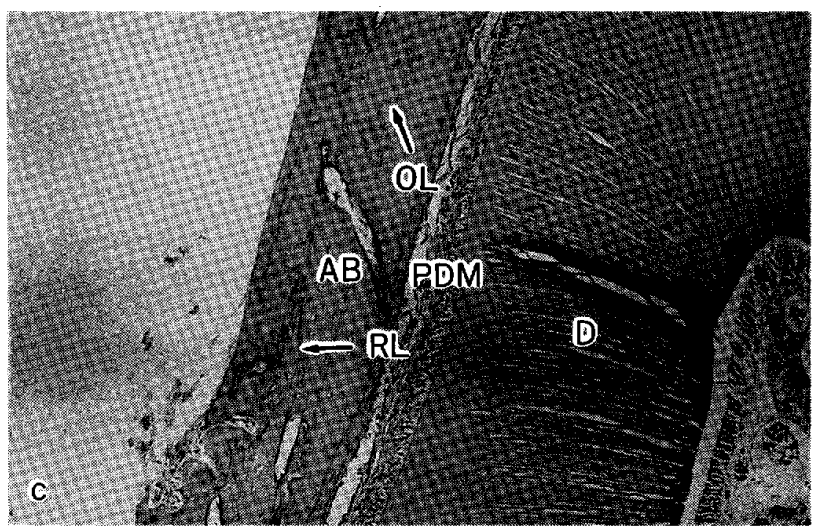

$\mathrm{H} \cdot \mathrm{E}$ stain $(\times 50)$

AB : Alveolar bone (central)

RL : Remodeling layer

PDM : Periodontal membrane

OL : Osteocytic lacunae

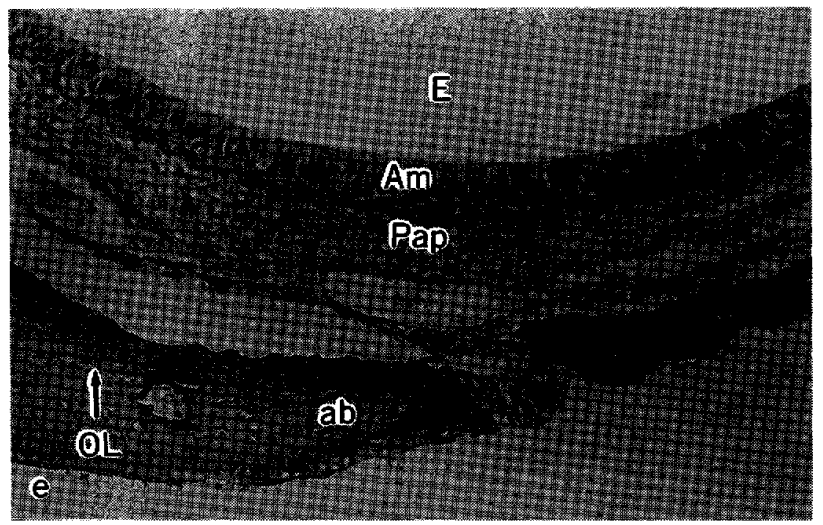

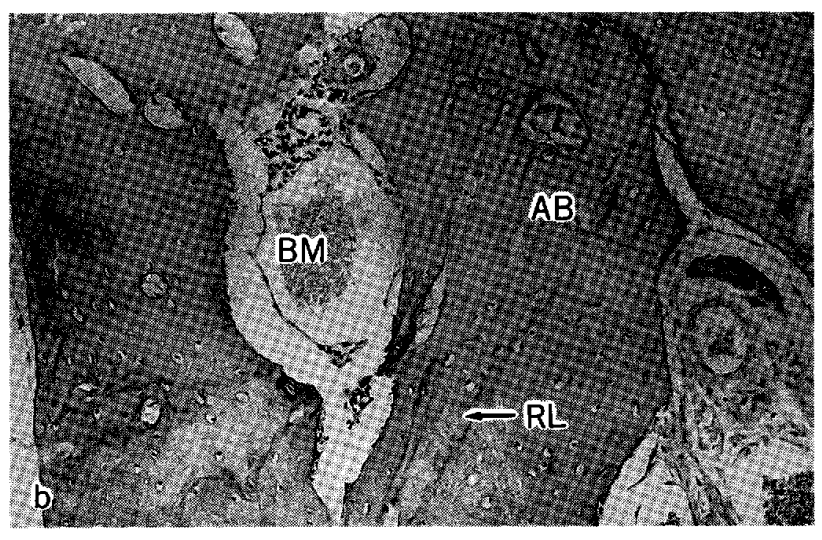

$\mathrm{H} \cdot \mathrm{E}$ stain $(\times 100)$

AB : Alveolar bone (lingual)

$\mathrm{BM}$ : Bone marrow

RL : Remodeling layer

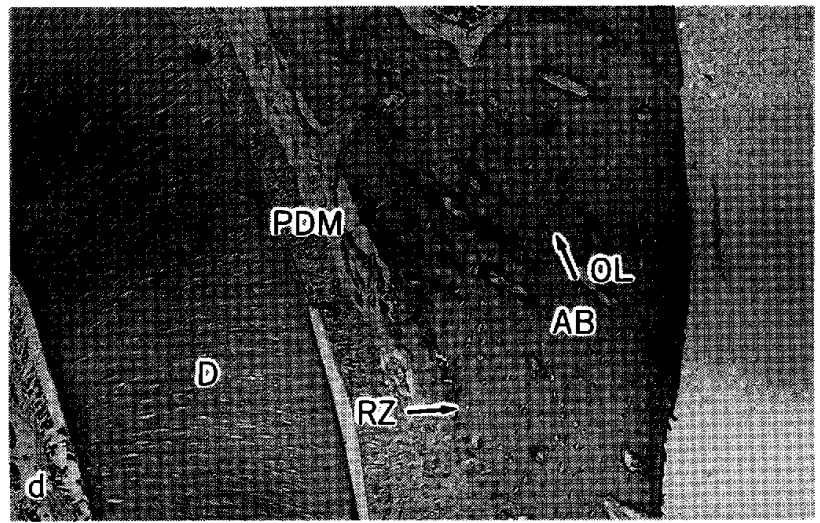

$\mathrm{H} \cdot \mathrm{E}$ stain $(\times 50)$

$\mathrm{AB}$ : Alveolar bone (buccal)

D : Dentin

RZ : Resorptive zone

PDM : Periodontal membrane

OL : Osteocytic lacunae

$\mathrm{H} \cdot \mathrm{E}$ stain $(\times 100)$

$\mathrm{ab}$ : Alveolar bone (labial)

$\mathrm{E}$ : Enamel

Am : Ameloblast

OL : Osteocytic lacunae

Pap: Papillary layer

Fig. 7 Alveolar bone of the 6 th week.

$\mathrm{Ca}-\mathrm{low}$ deficient diet group 


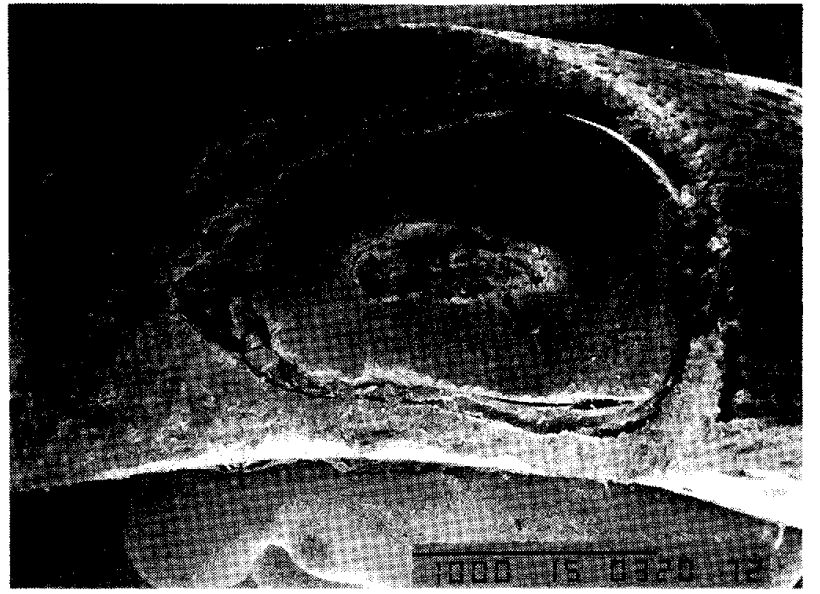

Fig. 8 Alveolar bone of the 6th week. (SEM) Control group

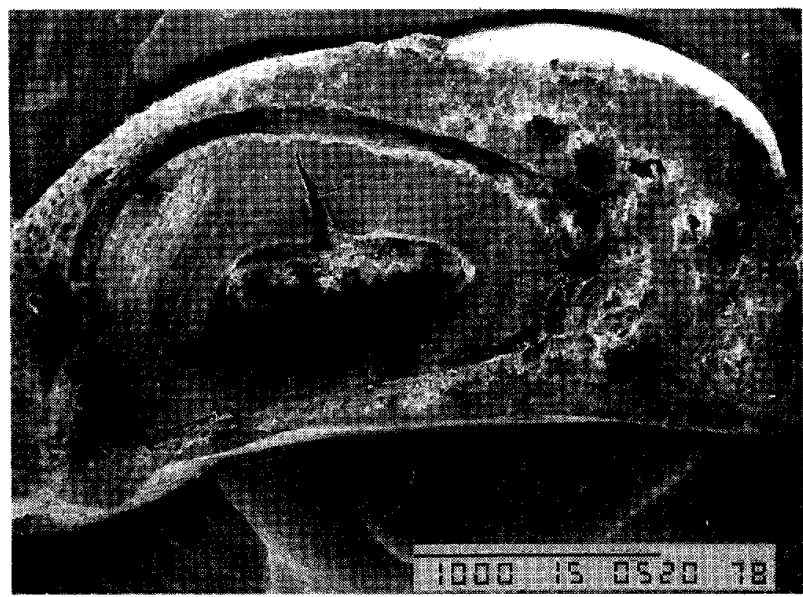

Fig. 10 Alveolar bone of the 6th week. (SEM) Ca-deficient diet group

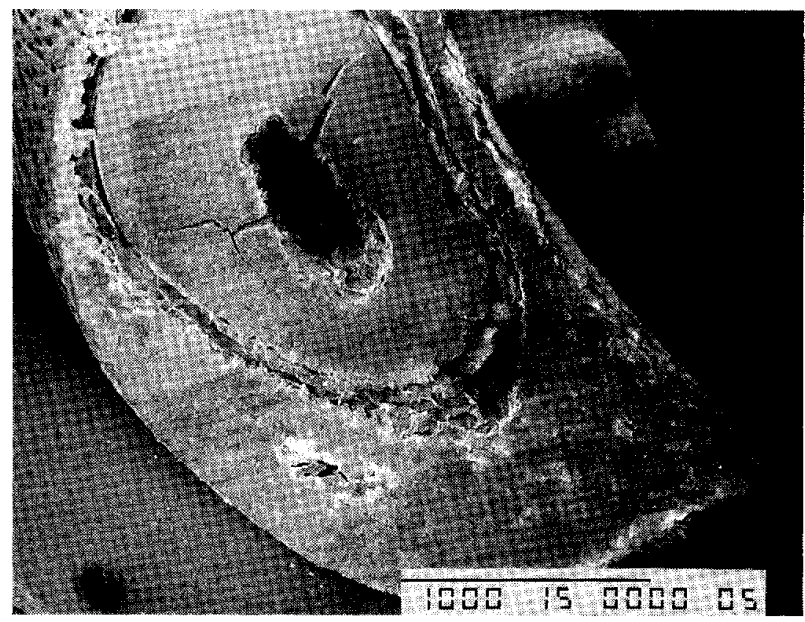

Fig. 12 Alveolar bone of the 6th week. (SEM) $\mathrm{Ca}-\mathrm{low}$ deficient diet group

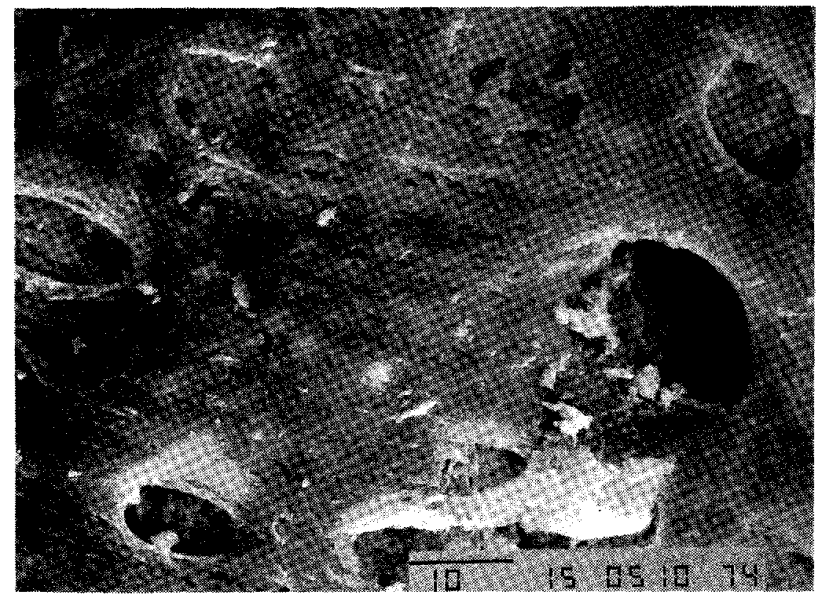

Fig. 9 A higher magnification of Fig. 8.

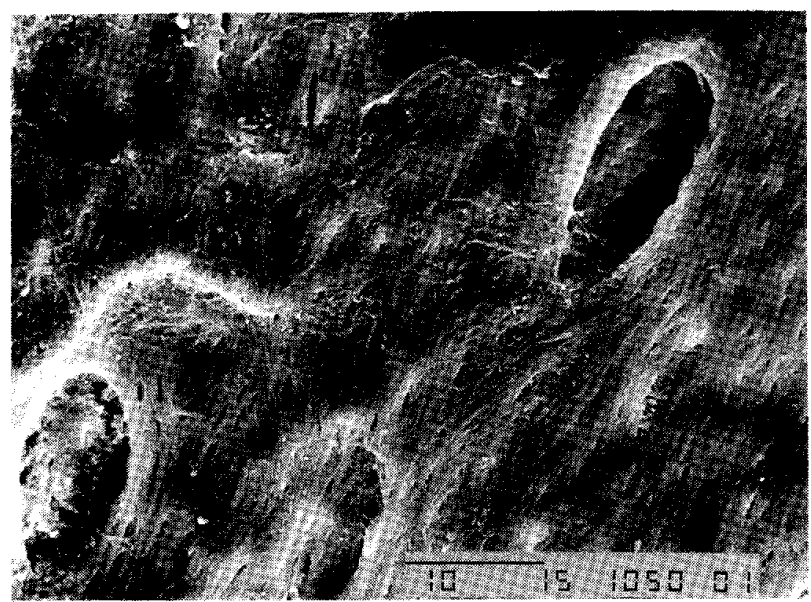

Fig. 11 A higher magnification of Fig. 10.

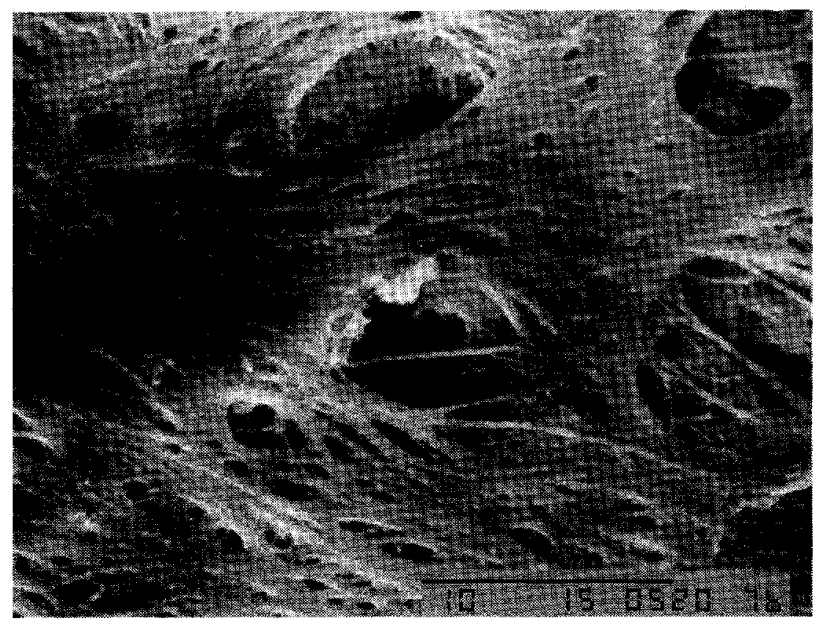

Fig. 13 A higher magnification of Fig. 12. 
considered to be resulted from bone resorption. On the formation surface of bone matrix, many irregular-shaped bone lacunae were frequently observed, and many of them had unclear division with the surrounding bone matrix (Figs. 10, 11).

Low calcium group

In comparison to the calcium deficient group, formation areas of bone matrix were more often observed. Many irregular-shaped bone lacunae were seen scattered and surrounded by particularly-alignmented collagen fibers, showing increased bone matrix formation. On the upper surface of bone matrix, collagen fibers were seen crossed into a network. Increased bone resorption surfaces were shown when compared to the control group (Figs. 12, 13).

\section{Discussion}

Childhood, also called the primary sexual characteristic stage, is an important phase in the process of the growth and development of the individuals. At this age level, the eruption of the primary dentition is completed and the primary teeth are supported by the mandibular alveolar bone, suggesting the importance of the growth of the mandibular alveolar bone during childhood. It is generally accepted that bone is composed of carbonate-apatite with a calcium-to-phosphorus ratio of about 2.0 in human beings. An osteoblast is a differentiated bone-forming cell responsible for bone formation via stimulating the synthesis of the matrix protein and the calcification of the matrix, while an osteoclast is a large multinucleated cell contributive to bone resorption and also bone remodeling, via secretion of organic acids to digest collagen fibers and to dissolve calcium salts ${ }^{2}$. The mandibular alveolus consists of the outer portion of compact (or dense) bone and the interior portion of spongy (or cancellous) bone. The spongy bone has fast metabolism and plays an important role in calcium metabolism. On the other hand, there is $99 \%$ of calcium present in bone and only $1 \%$ in cells, connective tissue and blood. Calcium and phosphate homeostasis is complex, yet three important hormones are responsible for modulating these minerals. $1,25(\mathrm{OH})_{2} \mathrm{D}_{3}$, the hormonal metabolite of vitamin D, stimulates intestinal calcium and phosphate absorption, bone calcium and phosphate resorption, and renal calcium and phosphate reabsorption, thus increasing the blood $\mathrm{Ca} \cdot \mathrm{PO}_{4}$ ion product; Parathyroid hormone acts directly on bone and kidney and indirectly on the intestine to maintain or restore the serum calcium level; and calcitonin, in contrast, inhibits the release of calcium from bone to decrease bone resorption. However, environmental factors, such as dietary treatments, seems more important, especially adequate dietary calcium intake and increased intestinal calcium absorption are necessary to the individuals at growing stage. Dietary protein is a key factor for the resorption and excretion of calcium. Appropriate exercise could increase bone mass. Recently, the popular food service industry has an adverse effect on the nutritional balance, leading to the deficiency of calcium and zinc, which is an essential trace element in body and an important component in bone matrix ${ }^{3)}$, but this phenomenon does not always happen when providing meals as a group because of its no unbalanced diet, especially on animal food ${ }^{4}$.

Naito et al. $(1998)^{5)}$ have examined the life-style influence on the prevention of osteoporosis 
in college students and found that adequate dietary calcium intake seems an important factor to prevent from osteoporosis. Especially the students, who have had the habit of eating small fish by 18 years old, are reported to have acquired higher bone mass.

It is necessary to consider the interactions among some factors affecting calcium resorption such as age, resorption quantity of calcium, and some nutrients coexisting with calcium salts ${ }^{2,6-8)}$

The results of this study suggested that the decreased formation of bone matrix could be observed in the individuals, who were deficient in calcium at their primary sexual characteristic stage, in spite that during their fetal period, lactation period, weanling period, and childhood adequate calcium was stored in the bodies, and in their later life dietary treatments were performed by giving the standard diet. Therefore, it is necessary to increase calcium and balanced protein intake in order to prevent from the low bone mass because calcium deficiency readily results in the decrease of spongy bone.

In the present study, the low calcium group showed the increased Haversian system number, and increased bone formation and remodeling, suggesting that the two-fold or threefold quantity of calcium intake may be necessary.

Nishida et al. $(1993)^{9)}$ have investigated the mandibular alveolar bone of the low-calcium rabbits and observed the increased bone resorption, particularly in the molar areas, suggesting the conditions of activity of osteocytes. Ohdani et al. (1992) ${ }^{10)}$ reported that the rapid bone resorption of alveolar bone in the molar areas in the low-calcium rats, which could not make bone lose its functions such as supporting teeth, could be improved by the mechanical powers such as occlusive power. Matsumoto et al. (1989) ${ }^{11}$ examined the mandibular condylar cartilages of the rats fed with low calcium diet. It was found that calcium deficiency in the growing rats inhibited the prolifiration and mature of chondocytes and the resorption of cartilages accompanied with the decreased calcification of caltilage matrix, and had an adverse effect on the normal endochondral ossification, suggesting the inhibition of the growth of mandibular condyles. Qin et al. (1998) ${ }^{12)}$ investigated the microanalysis for $\mathrm{Ca}$ and $\mathrm{P}$ and densitometric findings of mandibular alveolus of 3-week-old weanling rats who were fed the calcium deficient diet and then treated with high calcium diet, and found the difficulty in the restoration from the condition of bone loss to the normal. Also Qin et al. $(1998)^{13)}$ fed the 3-week-old weanling rats on the calcium deficient diet and low calcium diet, causing bone loss in them, and then treated them with the standard diet and oral administration of $1,25(\mathrm{OH})_{2} \mathrm{D}_{3}$. On the findings of microanalysis for $\mathrm{Ca}$ and $\mathrm{P}$, oral administration of $1,25(\mathrm{OH})_{2} \mathrm{D}_{3}$ seemed effective to the restoration of bone loss. But compared with the control group, the experimental groups administered $1,25(\mathrm{OH})_{2} \mathrm{D}_{3}$ showed lower density, suggesting this treatment could not entirely restore the bone loss resulting from the calcium deficiency during the weanling period.

Saito et al. $(1998)^{14)}$ used the rats corresponding to school childhood in human beings, in whom bone loss resulting from the calcium deficiency, then gave the dietary treatment and found that compared to the control group, the experimental groups given the dietary 
treatments showed decreased lamellae in spongy bone and imcomplete bone structure. On the other hand, Furuya et al. (1989) ${ }^{15)}$ reported that restoration of bone matrix formation could been seen in mandibles of the rats fed on the $20 \%$-low-calcium diet and then given the balanced standard diet.

Kimura et al. $(1996)^{16)}$ reported that bone restoration could be found in the mandibules of 8-week-old rats corresponding to puberty in human beings, in whom bone loss had been resulted from calcium deficiency, under the condition that peak bone mass was acquired by changing to take the balanced standard diet and restoring calcium in bone.

Peak bone mass is reported to be necessary for the prevention from bone $\operatorname{loss}^{17-20)}$ and it is known that remarkable increase of bone mass always happens at the second sexual characteristic stage $\mathrm{e}^{21}$, suggesting that adequate calcium intake is important for the growing individuals. Weinreb et al. (1991) ${ }^{22)}$ reported that no significant changes could been seen between the control animals and the low calcium animals who were in the period corresponding to school childhood in human beings. However, peak bone mass could be influenced by many factors such as the quantity of secretion of gonad hormone and parathyroid hormone, and the quantity of calcium intake ${ }^{23)}$, and also the connections between bone mass and heredity has been reported ${ }^{24)}$.

In the present study, the dietary treatment was performed on 5-week-old animals corresponding to childhood in human beings because in whom bone loss was caused. Of all dietary treatments, it is important and appropriate to choose a dietary treatment, which can stimulate intestinal calcium absorption and renal calcium reabsorption, and decrease renal calcium excretion. Therefore, for the growing individuals, it should be necessary to consider some factors related to calcium absorption and excretion while increasing calcium intake.

This study proved a fact that calcium plays a key role in bone resorption and formation, which are always associated with many kinds of mechanical stimuli such as occlusion and mastication. The changes of bone mass in labial alveolar bone are different from those in lingual alveolar bone, which possesses periodontal membrane. The reaction of spongy bone to the changes of bone mass is faster than that of compact bone, and readily occurs to change with the difference of calcium absorption in earlier time. The present study demonstrated that bone loss, which resulting from calcium deficiency during the earlier periods of the individuals, possibly led to insufficient calcium stored in bone; and bone loss could not be recovered even if excessive calcium was taken after the growing periods of the individuals, in contrast, excessive calcium readily led to unbalanced calcium absorption and excretion, suggesting that adequate calcium intake from balanced standard diet for a long time, at least up to the second sexual characteristic stage, might be very necessary and important for the later life.

\section{Conclusion}

In the present study, we fed 5-week-old Wistar male rats (corresponding to childhood in human beings) on calcium deficient diet and $30 \%$-low-calcium diet for 3 weeks so as to 
bring about bone loss in them, and then treated them with the standard diet for further 3 weeks. Later, we observed bone matrix formation on the mandible and obtained some findings as follows.

1. X-ray findings

The calcium deficient group showed the thin alveolus, and sparse and irregularly-arranged trabeculae. The low calcium group showed increased thickness of the alveolus when compared with the calcium deficient group, but showed sparse bone structure in an overall observation of the alveolus when compared to the control group.

2. Densitometric findings

The calcium deficient group showed significantly lower density compared with the control group $(\mathrm{p}<0.05)$.

3 . Findings of microanalysis for $\mathrm{Ca}$ and $\mathrm{P}$

The experimental groups showed lower relative ratio of $\mathrm{Ca}$ than the control group, but there is no significant difference between the experinmental groups. The relative ratio of $P$ showed a decreasing tendency on a sequence of the calcium deficient group, low calcium group and control group.

4. Histopathologic findings

We observed the lingual, medial, and buccal or labial alveolar bone in the mandibles. Compared with the control group, the calcium deficient group showed irregular periodontal membrane, and decreased bone lacunae and Haversian system number, suggesting markedly decreased bone matrix formation. The low calcium group showed increased Haversian system number and bone matrix formation when compared to the calcium deficient group, but insufficient bone remoddeling and restoration could be seen in the low calcium group when compared to the control group.

5. SEM findings

There is no obvious morphological difference among all the groups. Compared to the control group, the calcium deficient group showed increased large or small, and irregularshaped bone lacunae, which are considered to be associated with bone resorption. And bone lacunae, which had unclear division with the surrounding bone matrix, were more often seen.

In comparison to the calcium deficient group, the low calcium group showed increased bone lacunae scattered and surrounded by collagen fibers in a paticular aligument. Increased bone resorption surfaces were seen when compared to the control group.

The results of the present study suggested that it is very difficult to recover entirely from bone loss caused during the earlier periods especially in childhood, in spite of performing dietary treatments by taking balanced diet, and it is necessary to give calcium and some biological activators for a long time.

\section{Acknowledgments}

The authors greatly thank the director, Professor Mitustaka Kimura, and the staff of the Department of Pediatric Dentistry, Kyushu Dental College, for their help during this 
investigation.

This work was present in part at the 36th meeting of Japanese Society of Pediatric Dentistry on June 5 and 6, 1998 in Okayama, Japan.

\section{References}

1) Scammon, R. E.: The measurement of the body in children. In: The measurement of man (eds by Harris, J. A. et al.). University of Minnesota Press, Minneapolis, 1930.

2) Fujida, Y.: Calcium. Jpn Nutr. $34: 5-9,1991$. (in Japanese)

3 ) Kusano, S., Nishida, I., Maki, K., Gong, R. T., Ishii, K., Ohsato, Y., Yoshinaga, H. and Kimura, M.: Evaluation of minearls in eaten-out food. Jpn J. Pediatr. Dent. 32: 120-128, 1994. (in Japanese)

4 ) Kusano, S., Uchioka, M., Nishida, I., Maki, K., Morimoto, A., Ishii, K., Ohsato, Y., Zhou, S. H., Hideshima, O. and Kimura, M. : Evaluation of inorganic matter in school lunch. Jpn J. Pediatr. Dent. $32: 1042-1052$, 1994. (in Japanese)

5 ) Naito, M., Haruoka, M., Arizumi, T., Kusuzaki, H., Ueda, K. and Kimura, M.: Investigation of factors for osteoporosis prevention in college students 1 . Habits in daily life. Jpn J. Pediatr. Dent. $36: 896-901,1998$. (in Japanese)

6) Shangraw, F. R.: Factors to consider in the selection of a calcium supplement. Public Health Rep. 104 (suppl.) : 46-50, 1989.

7 ) Charles, P.: Calcium absorption and calcium bioavailabilities. J: Intern. Med. 231 : 161-168, 1992.

8 ) Riggs, B. R.: Panel session: Nutrition/exercise, panel summary. Public Health Rep. 104 (suppl.) : 34-36, 1989.

9 ) Nishida, A., Miyaguchi, H., Iwada, M., Tamashiro, T., Fujii, T. and Hagiwara, Y.: Resorption of alveolar bone in the mandible and the long bone in calcium-deficient rabbits. J. Fukuoka Dent. 20: 245-250, 1993. (in Japanese)

10) Ohdani, K., Amano, K. and Ogura, H.: Alveolar bone resorption process in molar tooth region in calcium-deficient rats. J. Oral Patholog. 59: 585-593, 1992. (in Japanese)

11) Matsumoto, F,: Histological observations on the mandibular condylar cartilage in growing rats on a low-calcium diet. J. Shikoku Dent. 3: 161-177, 1989.

12) Qin, M., Zhang, Z. Y., Maki, K., Morimoto, A., Murada, M., Ge, L. H. and Kimura, M.: A therapy study by $\mathrm{Ca} / \mathrm{P}$ microanalysis and bone mineral mass on the mandible of weaned rats. Jpn J. Pediatr. Dent. $36: 29-35,1998$. (in Japanese)

13) Qin, M., Zhang, Z. Y., Maki, K., Morimoto, A., Murada, M., Ge, L. H. and Kimura, M.: A therapy with calcium diet and active vitamin $\mathrm{D}_{3}$ study by $\mathrm{Ca} / \mathrm{P}$ microanalysis and bone mineral mass on the mandible of weaned rats -lower alveolar bone-. Jpn J. Pediatr. Dent. 36: 36-41, 1998. (in Japanese)

14) Saito, A.: Radiographic, microscopic and ultrastructural study on dietary treatment of mandibular bone loss at growth stage: Formation of bone matrix. J. Kyushu Dent. 52:1-32, 1998. (in Japanese)

15) Furuya, M.: The experimental study on changes of mandible by dietary treatment on $20 \%$ low calcium-induced bone loss in adolescent years: on bone matrix formation. J. Kyushu Dent. Soc. 51 : 800-820, 1997. (in Japanese)

16) Kimura, K.: An experimental study on a diet treatment method for juvenile debilitated bonemandible- . J. Kyushu Dent. Soc. 50: 883-905, 1996. (in Japanese)

17) Glastre, C., Brallion, P., David, L., Cochat, P., Meunier, P. J. and Delmas, P. D.: Measurement of bone mineral content of the lumber spine by dual energy $\mathrm{X}$-ray absorptiometry in normal children: Correlations with growth parameters. J. Clin. Endocrinol. Metab. 70: 1330-1333, 1990.

18) Bonjour, J. P., Theintz, G., Buchs, B., Slosman, D. and Rizzoli, R.: Critical years and stages of 
puberty for spinal and femoral bone mass accumulation during adolescence. J. Clin. Endocrinol. Metab. 73: 555-563, 1991.

19) Theintz, G., Buchs, B., Rizzolo, R., Slosman, D., Clavien, H., Sizonenko, P. C. and Bonjour, J. P.: Longitudinal monitoring of bone mass accumulation in healthy adolescents : Evidence for a marked reduction after 16 years of age at the levels of lumbar spine and femoral neck in female subjects. J. Clin. Endocrinol. Metab. 75: 1060-1065, 1992.

20) Tokida, S., Unno, A., Miura, U., Tawa, T., Ishikawa, A. and Yamashiro, Y. et al.: Prevention of osteoporosis since childhood. Juntendou Igaku 42:45-54, 1996. (in Japanese)

21) Aya, K. and Kyono, Y.: Osteoporosis in childhood. Jpn J. Pediatr. 38 : 1381-1387, 1997. (in Japanese)

22) Weinreb, M., Rodan, G. A. and Thompson, D. D.: Immobilization-related bone loss in the rat is increased by calcium deficiency. Calcif. Tissue Int. 48: 93-100, 1991.

23) Kyono, Y., Tanaka, H. and Hiroda, T.: Factors Related to Peak Bone Mass. The Bone 8: 16-34, 1994.

24) Nigel, A. M., Jian, C. Q., Akifumi, T., Paul, J. K., Linda, C., Tuan, V. N., Philip, N. S. and John, A. E. : Prediction of bone density from vitamin D receptor alleles. Nature 367:284-287, 1994. 


\title{
幼児期ラットの虚弱下顎骨における食餌療法に関する $\mathrm{X}$ 線的骨塩量, 光顕的および超微形態的研究
}

\author{
中島 龍 市・張祖 燕・戴 文 瑜 \\ 牧憲 司
}

九州歯科大学小児歯科学講座(指導：木村光孝教授)

ヒト幼児期に相当する 5 週秢の Wistar 系雄ラットを 30 匹使用し，カルシウム欠乏食と低カルシウム食 $30 \%$ を 3 週間与え虚弱骨を惹起した．直ちに標準食に切り換 え 3 週間飼育し，骨基質形成について検索し，以下の結 果を得た。

1. $\mathrm{X}$ 線学的可見

カルシウム欠乏食群の歯槽骨は細く，骨梁は疎で配列 屯不規則であった．低カルシウム欠乏食群は，カルシウ ム欠乏食群と比べ歯槽骨は厚さを増しているが対照群と 比べると未だ骨梁は疎な部分も多く認められた.

2. 骨塩量

3 群間では対照群と比ベカルシウム欠乏食群間には有 意差が認められカルシウム欠乏食群が低值を示した $(\mathrm{p}$ $<0.05)$.

3. X 線マイクロアナライザーによる $\mathrm{Ca}, \mathrm{P}$ の分析 相対カルシウム量比は, 対照群>カルシウム久そ食群 =低カルシウム食群で, 相対 $\mathrm{P}$ 量比はカルシウム欠乏食 群＞低カルシウム食群＞対照群の順であった。

4. 病理組織学的所見

下顎骨における舌側歯槽骨から，唇側歯槽骨，中央側 雬槽骨および煩側歯槽骨に至るまで観察した。
対照群に比ベカルシウム欠乏食群は一般に歯根膜の不 規則化，骨小腔の減少，ハバース系の減少が著明で骨基 質形成は低下していた。低カルシウム食群は，カルシウ ム欠乏食群に比ベハバース系の増加および骨の再構築層 が増加していたが，対照群に比べると骨の回復所見は不 十分であった。

5 . 走查型電顕学的所見

対照群に比べ形態的には何ら変化はみられなかった. 対照群に比べカルシウム欠之食群は骨吸収のため露出し た大小の骨小腔が多く，不定形を呈していた。 また，周 囲基質との境界が不明睹な部分す増加していた。 カルシ ウム欠乏食群に比べ, 低カルシウム食群は, 一定方向に 走行するコラーゲン原線維束によって骨小腔は囲まれ分 布量も増加していたが，骨吸収面は，対照群と比べ増加 していた.

以上の結果から，小児期の中であ特に低年齢児である 幼児期での虚弱下顎骨はバランスのとれた食慨療法では 骨基質形成が困難であることから，カルシウム療法と生 理活性物質との併用療法を長期間継続する必要があるこ とが示晙された。 